\title{
The Moderating Role of Staff Efficiency in the Relationship between Bank's Specific Variables and Liquidity Risk in Islamic Banks of Gulf Cooperation Council (GCC) Countries
}

\author{
Ghanim Shamas ${ }^{1,2}$, Zairani Zainol ${ }^{3} \&$ Zairy Zainol $^{3}$ \\ ${ }^{1}$ Salalah College of Technology, Salalah, Oman \\ ${ }^{2}$ PhD Student in Universiti Utara Malaysia (UUM), Malaysia \\ ${ }^{3}$ Islamic Business School (IBS), Universiti Utara Malaysia (UUM), Malaysia \\ Correspondence: Ghanim Shamas, Islamic Business School (IBS), Universiti Utara Malaysia (UUM), Room 207, \\ 11G1, Maybank, UUM, Malaysia. Tel: 601-0538-1848. E-mail: sandocana@ gmail.com
}

Received: November 4, 2017

Accepted: November 25, $2017 \quad$ Online Published: November 30, 2017

doi: 10.5539/ijef.v9n12p278

URL: https://doi.org/10.5539/ijef.v9n12p278

\begin{abstract}
The efficiency of bank's staff plays a crucial role in managing and mitigating the financial risks like liquidity risk. The aim of this paper is to propose a conceptual model/framework for investigating the moderating role of staff efficiency on the relationship between bank's specific variables and liquidity risk in Islamic banks in Gulf Cooperation Council (GCC). GCC economies depend heavily on oil revenues which makes them subject to oil prices fluctuations. Therefore, liquidity in GCC banks, especially Islamic banks almost always suffers liquidity pressure. Thus, the issue of liquidity in this region has grown in importance in light of recent oil decline. Several attempts have been made to investigate the determinants of liquidity risk, yet the findings lack consistency. Most of the previous studies have ignored GCC region and have focused on other environments like credit risk but gave less attention to the moderating role of staff efficiency function in the Islamic banks with respect to liquidity risk. This paper offers a framework by adding a moderator of staff efficiency to the existing models of the bank's specific determinants of liquidity risk with a particular attention to the GCC countries which are heavily dependent on oil revenues and always are subject to the impact of oil prices instabilities. Many stakeholders should benefit from the outcomes of this study. It should pave the way for bankers, regulators, investors and researchers to have a better understanding and insight about the factors that affect liquidity risk in the aforesaid banks.
\end{abstract}

Keywords: GCC, Islamic banks, liquidity risk, staff efficiency

\section{Introduction}

There is indeed a large number of research being conducted around the world investigating the impact of the bank's specific determinants on liquidity risk using different approaches. However, this paper has not come across any research work on the moderating role of staff efficiency on the relationship between bank's specific variables and liquidity risk.

Banks play a crucial role in the financial intermediation process, hence, having efficient and effective banking industry is an essential requirement for ensuring stability and growth of the economy (Halling \& Hading, 2006). In case of Islamic banks (IBs), the success of (IBs) is a result of many factors, but the important one is liquidity management (Al Faris \& Al Zararee, 2011).

As long as the financial intermediation theory is concerned, the main duty of a modern financial intermediary is to provide liquidity and financial services. Liquidity has significant functions on both levels, on the economy level and at the bank level. At the economy level, liquidity plays key function in liquidity creation. This liquidity creation is considered the primary cradle of economic welfare provided by banks but also as their main cause of risk (Akkizidis \& Khandelwal, 2008; Diamond \& Dybvig, 1983; Calomiris \& Kahn, 1991).

At the bank level, liquidity can determine the survival and the competitiveness of the bank. The shortage of liquidity is being labeled the assassin of banks and liquidity excess is considered a drag on competitiveness (Chagwiza, 2014). Therefore, from the liquidity's definition which is the bank's ability to fund an increase in 
assets and pay the due financial obligations, without encountering intolerable losses (Bank for International Settlement (BIS), 2008), liquidity management has become a vital aspect in bank's success.

This fundamental task of banks is seen in the process of accepting deposits and providing loans, in banking this is known as the intermediation approach. Naturally, this process makes banks to become prone to financial risks. One of the significant financial risks facing banking industry today is liquidity risk. It is known from existing literature that liquidity shortage could lead to high liquidity risk which may eventually cause bankruptcy (Salameh, 2014; Ali, 2007). Given the importance of liquidity risk in banking, recently researchers have shown an increased interest in liquidity risk. However, previous researchers have ignored liquidity risk in GCC, although liquidity plays a vital role where it depends heavily on oil revenues which is the main source of GCC national economies.

GCC states are oil exporters and any changes in international oil prices can impact their GDP growth, government budgets, fiscal revenues, development programs and exports. Resultantly, this heavy oil-dependency reflects a high level of exposure of GCC economies to external shocks that could further threaten the financial markets and the stability of banking systems. This association presents risks and induces significant liquidity volatility for banks (Al-Hassan, Oulidi, \& Khamis, 2010; Khandelwal, Miyajima, \& Santos, 2015; Alodayni, 2016).

This was clear with the fall of the oil price at the end of 2014. The recent decline in the oil prices has led to liquidity decrease in the banking sector, credit growth and weaknesses bank's balance sheets. Gulf governments withdrew their deposits - which are the main source of funding for IBs - resulting in a negative effect on Islamic banks' liquidity (Khandelwal et al., 2016; Mahmoud, 2016).

The existing literature has neglected liquidity risk in GCC region. Still, the problem of liquidity risk in GCC has remained unanswered and not fully understood due to the lack of the research. This paper intends to fill the gap by proposing a model that can be used to explain this problem and contribute to the literature by introducing a moderating variable of staff efficiency in the relationship between bank's variables and liquidity risk by using IBs in GCC countries.

The paper proceeds as follows: Section 2 introduces liquidity risk \& banking liquidity position in GCC states. Section 3 discusses various literature related to bank's specific variables of liquidity risk. Section 4 introduces the moderating variable of staff efficiency and proposed a theoretical framework. Section 5 covers policy implications and section 6 ends with recommendations and conclusions.

\section{The Related Literature Review}

This section is divided into two sections, liquidity risk and overview of liquidity risk position in GCC states and it discusses the related literature.

\subsection{Liquidity Risk}

Liquidity risk arises from the fundamental role of banks in the maturity transformation of short-term deposits into long-term loans. In respect to Islamic banks, liquidity risk is defined as the potential loss to the Islamic banks ascending from their inability to meet their financial duties as they fall due without incurring unacceptable costs or losses (Shaikh, 2015).

Another similar definition is provided by Nimsith and Shibly (2015) stating that liquidity risk occurs where the bank becomes incapable either to meet the obligations of the depositors or to fund increases in assets as they come due without experiencing intolerable costs or losses. The latter definition shows the two types of liquidity risk, namely market liquidity risk and funding liquidity risk.

According to IFSB (2012), funding liquidity risk occurs when the Islamic Institutions of Financial Services (IIFS) become unable to meet efficiently both its expected and unexpected current and future cash flows and collateral needs without affecting either daily operations or the financial condition of the IIFS. On the other hand, market liquidity risk is the risk that IIFS cannot easily offset or eliminate a position at the market price because of inadequate market depth or market disruption (IFSB, 2012). Based on the above definitions it is obvious that liquidity risk management is critical to bank's survival. It should be noted that liquidity risk occurs due to dynamics of maturity mismatch.

Maturity mismatch generates liquidity risk when financial institutions roll over their short-term debts, it (maturity mismatch) results from the maturity of assets being usually longer than the maturity of financing (Bessis, 2011). This can hinder the success of financial institutions.

Al Faris et al. (2011) argued that the success of IBs is a result of many factors, but the important one is liquidity 
management which encourages customers to deposit their funds or to borrow funds for investment. However, liquidity can be adversely affected by economic disruptions like the financial crisis.

The financial crisis of 2008 - which was caused by U.S. subprime assets - had an indirect impact on banking and corporate liquidity and funding costs in GCC (Kumah, Hasan, Khamis, Prasad, Semlali, \& Sensenbrenner, 2010). Bessis (2011) emphasized that liquidity risk is reliant on market disruptions in the whole financial system, as the sub-prime crisis of 2008 showed.

Henceforth, in the new global economy, liquidity risk has become a central issue for bankers and regulators. The reason the liquidity risk has gained a big attention is because liquidity shortage was one of the main challenges faced by financial institutions in 2008 financial crisis. The crisis stressed weakness in the field of liquidity risk management because banks have shown the absence of good forecasting techniques to manage liquidity risk, which has led to a liquidity challenge and exuberate sudden decline of bank's balance sheets with consequent difficulties in finding fresh sources of liquidity on interbank markets. In response to this crisis, the Basel Committee issued new principles and guidelines on liquidity risk management in December 2010 (Cucinelli, 2013). Hence, following the issuance of Basel 3 regulation, it is becoming extremely difficult to ignore the study of liquidity and liquidity risk determinants. Furthermore, it appears that the shortage and surplus of liquidity in Islamic banks have shown paradoxical phenomenon which means Islamic banks always seem to be challenged by high and/or low liquidity levels.

Liquidity deficiency and liquidity surplus have always imposed serious challenges for Islamic banks.

When there is a shortage of liquidity, institutions offering (IIFS) face limitations in tools for managing liquidity. (IIFS) cannot utilize any interest-bearing instruments related to money market and lack the access to central bank window facilities (Majid \& Rais, 2003; Ahmed, Akhtar, \& Usman, 2011). These tools and other liquidity facilities are at the disposal of conventional banks.

On the contrary, excess liquidity has been one of the liquidity challenges for Islamic banks. Boumediene (2015) argued that IBs in fact are facing a dilemma in terms of liquidity management. Similarly, Ali (2013) found that IBs in general are having a higher amount of liquid assets than conventional banks. The liquidity of Islamic banks was double the liquidity of conventional banks in the financial crisis of 2009 (Ali, 2013). Moreover, he stated that the liquidity surplus is becoming something from the past and potentials of liquidity scarcities are rising.

Nowadays, liquidity risk has developed to become a fundamental issue in Islamic and conventional banks. Besides, since the nature of IBs is centered on dealing with real assets, this makes them exposed more to liquidity risk, (Shibly et al., 2015). What even makes liquidity management to be more challenging in IBs is the limited means to deal with liquidity issues.

In its report of 2015, Islamic Finance Service Board (IFSB) emphasized that due to the absence of tradeable Sharia's compliant tools - which can serve as high quality short-term liquid assets- liquidity management has become perpetual anxiety for the Islamic institutions (IFSB, 2015). This report stated that majority of the current IBs are involved in bilateral investment based (Mudarabah) deposit placements with each other to mitigate liquidity matters. It is estimated that nearly half-trillion dollars are required for liquid securities and short-term credible for capital management purposes (IFSB, 2015).

Another significant aspect of liquidity risk is its measurements. The existing literature shows divergent views among researchers on how to measure liquidity risk. Most of the researchers used simple calculation as a proxy to describe liquidity risk. Researchers like Nemati, Ghanbari, and Mohammadipour (2015); Jedidia and Hamza (2014); Ramzan and Zafar (2014); Anam et al. (2012) and Anjum Iqbal (2012) used "Cash to Total Assets, (CTA)" as a proxy for liquidity risk. Sulaiman, Taqiuddin, and Samsudin (2013) and Ahmad Azam et al. (2013) utilized "total deposits to total assets" while Abdullah and Khan, (2012) extended the proxy using "capital to total assets" ratio. The ratio of "Liquid Assets to Deposits and Short-Term Borrowing, (LADSTB)" has been used by (Ariffin, 2012).

For this paper we propose the use of "CTA" ratio and "Liquid Assets to Deposits and Short-Term Borrowing, (LADSTB)" ratio as proxies to measure liquidity risk. "CTA" is found to be the most frequent ratio used as a proxy for liquidity risk. For (LADSTB), this proxy is consistent with the proposal of Bank Negara Malaysia for measuring liquidity risk, (Ariffin, 2012).

\subsection{Overview of Banking Liquidity Position in GCC States}

The year of 1981 witnessed the birth of the Gulf Cooperation Council (GCC). GCC constitutes of Kuwait, Oman, Qatar, Saudi Arabia, Bahrain and UAE. These countries are the major suppliers of oil in the global energy 
markets and their economies depend heavily on oil revenues. This implies that economically these countries are highly integrated into the global economy and have a big impact on the world's largest economies that are dependent on oil (Ravichandran \& Alkhathlan, 2010; Al-Khouri \& Dhade, 2014).

Since GCC are heavily dependent on oil revenues consequently any changes in international oil prices immediately impact their GDP growth, government budgets, fiscal revenues, development programs and exports. Thus, this heavy oil-dependency reflects a high level of exposure of GCC economies to external shocks that could further threaten the financial markets and the stability of banking systems. This linkage presents risks and instigates significant liquidity volatility for the banking sector (Al-Hassan et al., 2010; Khandelwal et al., 2015; Alodayni, 2016).

The banking sector is the backbone of GCC national economies. The sector is the second highest contributor to the country's GDP after oil and gas. This vital industry which generally dominates the financial sector in these countries is one of the most economically viable diversification options (Al-obaidan, 2008; Abu Loghod, 2010; Al-Hassan, Khamis, \& Oulidi, 2010; Mohanty, Aljuhaniand \& Bardesi, 2016). In terms of IBs growth, GCC has the lion share in this fast-growing banking segment.

Globally, the Gulf Cooperation Council (GCC) has the biggest share of Islamic financial assets, accounting for almost $40 \%$ of the global Islamic Financial Service Institutions (IFSI) in 2016 compared to $37.6 \%$ in 2015, (Islamic Financial Services Board, 2016). Table 1 shows that the total assets of Islamic banks in GCC countries is near $\$ 600$ billion.

Table 1. The global segmentation of Islamic finance (2015, in USA Dollars)

\begin{tabular}{ccccc}
\hline Region & Banking Assets & Sukuk Outstanding & Islamic Fund's Assets & Takaful Contribution \\
\hline Asia & 209.3 & 174.7 & 23.2 & 5.2 \\
GCC & 598.8 & 103.7 & 31.2 & 10.4 \\
MENA (exc. GCC) & 607.5 & 9.4 & 0.3 & 7.1 \\
Sub-Saharan Africa & 24.0 & 0.7 & 1.4 & 0.5 \\
Others & 56.9 & 2.1 & 15.2 & - \\
Total & 1496.5 & 290.6 & 71.3 & 23.2 \\
\hline
\end{tabular}

Source: Stability report, 2016; Islamic Financial Services Board (p. 7).

Over the last 6 years GCC governments have increased the wages of public sectors, which led to high growth of deposits in the private sector and high borrowing activities by individuals. Accordingly, this has produced a high exposure to liquidity risk especially with the recent fall in oil prices (Al-Khouri, 2012).

At the end of 2014 the decline of the oil prices has triggered the decline of bank's liquidity, weaknesses bank's balance sheets and growth of credit. GCC governments withdrew their large deposits which are the main source of funding for Islamic banks. This move resulted in a negative effect on Islamic banks' liquidity, (Khandelwal et al., 2016; Mahmoud, 2016).

Based on the above discussion, it becomes imperative to conduct this study as an initial attempt to explore the factors affecting liquidity risk in IBs in the GCC countries as these factors being overlooked by previous researchers.

\section{Bank's Specific Determinants of Liquidity Risk}

There are several bank's specific variables that can impact bank's liquidity risk. Researchers like (Anam et al. (2012); Anjum Iqbal (2012); Abdullah et al. (2012); Ariffin (2012); Al-Khouri (2012); Sulaiman et al. (2013); Ahmad Azam et al. (2013); Ramzan et al. (2014); Jedidia et al. (2014); Nemati et al. (2015); Iqbal, Ibrahim, and Murtaza (2015); Yaacob, Rahman, and Karim (2016), and more recently Zaghdoudi and Hakimi (2017) and Abdul Ganiyy, Zainol, and Ahmad (2017) have studies the linkage between bank's specific determinants and liquidity risk in banks, mainly Islamic banks.

All these researchers conducted empirical research and have shown that bank's specific variables namely Non-Performing Loans (NPL), bank's size, capital and profitability have significant relationship with bank's liquidity risk. Following the aforementioned researchers whom investigated the association between bank's specific variables and liquidity risk the same variables can be used again in the proposed study. However, what is less clear is the nature of the relationship between bank's internal variables and liquidity risk.

The current literature reveals research gaps about the determinants of liquidity risk in GCC Islamic banks. Firstly, past research has failed to give a sufficient consideration to the determinants of liquidity risk in IBs in GCC 
countries. Secondly, both prior and recent studies concerning financial risk in GCC banks have shown a great emphasis on either credit risk and performance or credit risk and oil prices (Grassa, 2012; Al-Khouri, 2012; Al-Wesabi \& Ahmad ,2013; Al-Tamimi, Miniaoui, \& Elkelish, 2015; Khandelwal et al., 2016; Alodayni, 2016). However, not many recent studies have focused on liquidity risk, although credit risk is theoretically and practically closely related to liquidity risk, (Diamond \& Rajan, 2005; Acharya \& Viswanathan, 2011; Gorton \& Metrick, 2012; and Imbierowicz \& Rauch, 2014). This creates a gap in the existing literature where determinants of liquidity risk in GCC banks have been neglected. In addition, past research concerning liquidity risk determinants have shown conflicting results and lack of agreements in their conclusions. What is not yet clear is the impact of bank's specific factors on the bank's liquidity risk in GCC Islamic banks. This indicates that there is a need to conduct the current study to fill the gap.

There has been extensive research on the impact of bank's specific determinants on liquidity risk in the banking industry. These determinants are also called internal determinants or internal factors which are specific variables to the bank. Appendix-A shows the most related empirical studies investigating liquidity risk by prior researchers conducted in various regions. Generally, the literature on liquidity risk in banking can be divided into two big strands. The first strand investigates the determinants of liquidity risk where the second strand evaluates the linkage between liquidity risk and profitability.

In the following paragraphs the two strands will be discussed including the proposed bank's internal variables.

\subsection{Non-Performing Loans (NPLs) and Liquidity Risk}

Loans become non-performing loans (NPLs) when it becomes likely that the borrower will not pay back the loans to the lender. NPLs in Islamic banks are proxied by impaired loans to gross loans. Performing loan to total loans is a measure of the quality of assets (Babihuga, 2007). Moreover, Lanine and Vennet (2006) emphasized that a big quantity of non-performing loans has been commonly seen in portfolios of failing banks.

Some researchers have used NPLs in their empirical studies on liquidity risk; including Arif et al. (2012); Vodová (2013); Sohaimi (2013); Ghenimi and Omri (2015); Shaikh (2015) and Zaghdoudi and Hakimi (2017). Ahmed et al. (2011) and Ghenimi et al. (2015) both reported that NPLs have a negative influence on the liquidity risk of Islamic banks in Pakistan and GCC respectively. In a recent study, Zaghdoudi et al. (2017) found that credit risk is positively and significantly correlated with the liquidity risk. The authors argued that the rise of this risk leads to the drying up of bank's liquidity and the rise of liquidity risk threatening the bank's sustainability.

In line with the views of the studies by Arif et al. (2012), Vodová (2013), Sohaimi (2013), Ghenimi et al. (2015) and Shaikh (2015), this paper proposes the adoption of impaired loans to gross loans as a proxy of non-performing loans in relation to liquidity risk.

\subsection{Bank's Size and Liquidity Risk}

Bank's size is another potential factor that affects the liquidity risk in Islamic banks. Bank's size is a common variable in liquidity risk's literature. Natural logarithm of total assets of the bank is used to measure bank's size.

It's been found that size of the bank can have an association with liquidity risk. In GCC environment, Ghenimi et al. (2015) noted that bank size has a negative impact on liquidity risk when liquidity risk is measured by the liquid asset to total asset.

Different from the findings of Ghenimi et al. (2015), Ahmed et al. (2011) found that Islamic bank's size has a statistical and significant positive linkage with liquidity risk. Similarly, Iqbal (2012) reported a positive and significant association between the bank's size with the liquidity risk.

These results are supported by the findings of Anam et al. (2012) who documented that size of the bank has positive and significance for IBs liquidity risk. In the same vein, Nimsith and Shibly (2015) found that the relationship of the size of a financial institution with liquidity risk management is positive but not significant in IBs. In addition, a positive association between the bank's size and liquidity risk has been found by Ramzan et al. (2014), Vodová (2013), How, Karim and Verhoeven (2005) and Ahmed et al. (2011).

Unlike these researchers, studies by Aldoseri (2012) and Anam et al. (2012) reported a negative association between conventional bank's size and liquidity. Recently, Zaghdoudi and Hakimi (2017) found that bank's size impacts negatively and significantly liquidity risk. Similarly, AbdulGaniyy et al. (2017) established that bank's size has been found to have a negative sign with liquidity risk in Malaysian banks.

Yet, Moussa (2015) claimed that size does not have a significant impact on bank's liquidity. Equally, Jedidia et al. (2014) stated that bank's size is not a factor effecting Islamic banks' liquidity risk. Similarly, Ahmed et al. (2011) reported insignificant relationship. While Anam et al. (2012), Sabri (2014); Ramzan et al. (2014) reported a 
positive relationship between bank's size and liquidity, Sulaiman et al. (2013) concluded that the relationship is negative. Irrespective of their inconsistent findings, many of the previous researchers have used one common proxy for bank's size, natural logarithm of total assets.

In a similar fashion to the previous studies, this paper recommends the use of natural logarithm of total assets of the bank to measure bank's size.

\subsection{Capital Adequacy Ratio (CAR) and Liquidity Risk}

Capital adequacy ratio (CAR) is another commonly used bank's determinant of liquidity risk. It measures the ratio of a bank's capital to its risk. It is used to measure a bank's readiness to absorb a reasonable amount of loss and fulfills statutory capital requirements. The ratio is used to shield depositors and encourage stability and efficiency of financial systems.

Greuning and Bratanovic (1999) maintained that the bank's capital directly or indirectly impacts every aspect of banking operations. Thus, the capital of a bank acts as a buffer against credit and operative losses of a bank as well as possible liquidity shortages (Ahmed, 2011). Capital in the banking system increases the trust of depositors and indirectly reduces the liquidity risk (How et al., 2005).

Bank's capital adequacy and liquidity risk have been much discussed by the earlier researchers (Jedidia et al., 2014; Anam et al., 2012; Ghenimi et al., 2015; Murtaza, Ibrahim, \& Hussain, 2015 and Nimsith et al., 2015). These studies showed conflicting results and lack of consistency.

According to Iqbal (2012), there is a significant and positive relation between CAR and liquidity risk. This was supported by the recent study of AbdulGaniyy et al. (2017) who reported positive linkage between CAR and liquidity risk in Sudan.

Ahmed et al. (2011) reported that CAR has a negative and significant relationship with credit and operational risk. Similarly, Nimsith et al. (2015) found a negative but insignificant relationship between liquidity risk and CAR. Equally, Murtaza et al. (2015) empirically proved that CAR has a negative and significant influence on liquidity risk in IBs in Pakistan. This was confirmed by the findings of AbdulGaniyy et al. (2017) who showed that CAR has a negative association with liquidity risk in Malaysian banks.

CAR is proxied by the ratio of equity to total assets, another proxy is "CAR = Tier1 plus Tier 2" all divided by Risk Weighted Assets. For the objective of this paper it is suggested to use equity to total assets ratio.

\subsection{Profitability and Liquidity Risk}

In the literature of liquidity risk, a big share of the previous research has been dedicated to the relationship between profitability and liquidity risk and how they influence one another.

It should be noted that there is a trade-off between liquidity and profitability and adequate balance has to be established between the two, otherwise liquidity position or profitability level can be jeopardized. Return on Assets (ROA) and Return on Equity (ROE) are profitability measures which are the two most frequently used in performance and profitability literature. However, there are other variations for these two measurements.

Return on Average Assets (ROAA) is measured by the ratio of net profit to the average of total assets. Hassan and Bashir (2003) stressed that ROAA shows the profit earned per dollar of assets and most importantly it reflects the management ability to utilize the bank's financial and real investment resources to generate profits. In the banking sector, ROAA depends on the bank's policy decisions as well as uncontrollable factors relating to the economy and government regulations (Sufian \& Habibullah, 2009). Many regulators believe ROAA is the best measure of bank profitability (Hassan et al., 2003).

It was suggested by Rivard and Thomas (1997) that bank profitability is best measured by ROAA in that ROAA is not distorted by high equity multipliers and ROAA represents a better measure of the ability of the firm to generate returns on its portfolio of assets. Return on Average Equity (ROAE), on the other hand, reflects how effectively a bank management is using its shareholder's funds. Since returns on assets tend to be lower for financial intermediaries, most banks utilize financial leverage heavily to increase return on equity to a competitive level (Hassan et al., 2003).

Like the impact of other bank's specific variables on liquidity risk, the association between profitability and liquidity risk is not clear. Murtaza et al. (2015) found that ROE has a negative and significant influence on liquidity risk in IBs. Similar results were found by Nimsith et al. (2015) who established that the relationship of ROA with liquidity risk is negative and not significant in the IBs and positive and significant in the conventional banks. 
(ROAA) and (ROAE) have been used by several researchers including Kosmidou, Tanna, and Pasiouras (2005), Said et al. (2011), Grassa (2012), Wasiuzzaman and Gunasegavan (2013), Ferrouhi (2014) and Garcia and Guerreiro (2016). Kosmidou et al. (2005) reported a positive association between ROAA and liquidity risk. Similarly, Wasiuzzaman et al. (2013) found a positive relationship between liquidity and the ROAA of conventional and Islamic banks in Malaysia. These conclusions are supported by the findings of Bashir (2003), Srairi (2009) and Wasiuzzaman and Ahmed Tarmizi (2010) who found a strong positive relationship between liquidity ratio and bank's profitability.

For the objective of the proposed research this study recommends the usage of (ROAA) and (ROAE) in measuring profitability because they are not misled by high equity multipliers and they showed better indicators of the bank's ability to generate profit. In the same way, these ratios show bank' effectiveness in using bank's funds (Hassan et al., 2003; Thomas, 1997).

As much as these bank's specific variables can have a significant impact on the bank's liquidity risk, bank's internal management and internal resources can do so much in mitigating such effects thus protecting bank's risky assets. The banks can depend significantly on the capabilities of their internal resources in ensuring that their liquidity risk is properly managed. More importantly, banks facing liquidity risk can also depend on staff efficiency in sustaining their good liquidity positions like the case of GCC countries.

\section{The Moderating Role of Staff Efficiency}

This is a new bank's specific variable. The resource-based theory stipulates that knowledgeable staff is more able to contribute towards firm's efficiency, generate revenues and profit. Mohd-Sultan (2008) argued that human resource efficiency is the most vexing managerial issue in Islamic finance system where lack of skills, knowledge and incompetence workforce will lead to higher operational and credit risks which stifle the Islamic banks' growth potential. To narrow this down to liquidity management, having knowledge of how liquidity flows and how to forecast liquidity is imperative in liquidity management and resource management in IBs (Ghaderi et al., 2013).

In addition, the theory of financial intermediation from the Islamic banking perspective stressed that the Islamic banking is not just intermediaries but also a business entity to run the provided capital by the depositor or capital provider (Nor et al., 2015). In a similar token, Bariah, Hubeis, and Hafidhuddin (2015) quoted Danuwirana (2012) stressing that Islamic human resources are required to have core competence in various areas including functional (expert in Islamic economics, banking operations, finance administrations, financial analysis) and managerial skills.

Zeti (2007) stressed (as cited in Obeidat, 2016) that the fast growth of Islamic financial industry and its increasing global significance is in urgent need for skilled human capital as the pivotal component in order for this Islamic financial sector to enhance their performance and competitiveness. From an Islamic perspective, Arshad, Noor, and Yahya (2015) emphasized that staff within the organization are indeed required to be talented in managing risks and opportunities with regards to the economic, social and environmental dimensions.

Linking the above discussions to GCC context, a study by Kumah et al. (2010) has pointed out that banks in GCC suffer from weakness in liquidity risk management. For this reason, it became urgent to investigate the staff efficiency in risk literature and more importantly in liquidity risk research in GCC banking sector.

There is handful number of research on the moderating role of staff efficiency in financial risk literature. Nor et al. (2015) reported high significant level (0.01) of the impact of staff efficiency on reducing impaired financing (credit risk). The authors stressed that banks' management should give identical importance on increasing the role of staff efficiency in managing credit risk. They found that this variable significantly moderates the association between impaired financing with loan growth, profitability and capital ratio. Likewise, Ahmad and Ahmad (2004) showed that credit risk and management efficiency in Islamic banks are significantly associated. Al-Wasabi et al. (2013) documented that credit risk determinants for IBs are similar to the determinants in traditional banks, such factors are portfolio's risk assets, quality of the management and liquidity.

Ibe (2013) highlighted that banks are encouraged to involve skilled and competent staff to ensure that correct decisions are executed, particularly with the adequate amount of liquidity and maximizing profit at the same time. Staff efficiency can be seen as another form of management efficiency. Previous researchers have used management efficiency where they used "earning assets to total assets of bank" as a proxy to measure management efficiency (Ahmed \& Ahmed, 2004). Furthermore, staff efficiency can be measured by "personal expenses to net income" as in (Nor \& Ahmed, 2015; Al-Wasabi \& Ahmad, 2013).

In line with the views of Nor and Ahmed, (2015), Al-Wasabi and Ahmad, (2013), and Ahmad and Ahmad (2004), 
this paper proposes the adoption of "personal expenses to net interest income" ratio as a means of measuring staff efficiency.

With respect to liquidity risk, earlier research has ignored staff efficiency which creates a gap in the existing literature. Nor et al. (2015) focused only on credit risk and this variable has not been yet tested on liquidity risk. in conjunction with this, since other risks like credit, market and operational risks directly or indirectly have impact on liquidity risk, AbdulGaniyy et al. (2017), it can be suggested that staff efficiency should be used as a moderator variable between bank's specific variables and liquidity risk.

This study could be the first study to include this variable in liquidity risk literature in Islamic banks. Additionally, the limited usage of staff efficiency variable in the literature of financial risk and the conflicting results in the current literature on relationship between bank's specific and liquidity risk makes it necessary to include it as moderating variable.

Sharma, Durand, and Gur-Arie (1981) accentuated that in some cases the predictive efficacy or the form of relationship between independent variables and dependent variable may vary as a function of some other variables. Sharma et al. (1981) and Baron and Kenny (1986) describe the nature of a moderating variable as variable that affects the direction and / or strength of the relationship between independent variables and a dependent variable.

Thus, it is crucial to investigate the moderating role of staff efficiency on the relationship between bank's variables and liquidity risk. Therefore, there is a need to investigate the moderating impact of staff efficiency on the association between bank's variables and liquidity risk with the expectation that the results could have importance in helping GCC banks to pay more attention to the significance of the staff efficiency and their essential role in managing liquidity risk.

In summary, bank-specific factors such as profitability (ROAA, ROAE), capital, non-performing loans (NPLs) and bank's size all have empirically shown a significant association with bank's liquidity risk. Deteriorations in these determinants can impose real difficulty regarding the liquidity position in GCC banks.

Figure 1 shows the proposed framework for the relationship between bank's specific variables and liquidity risk of GCC Islamic banks moderated by staff efficiency.

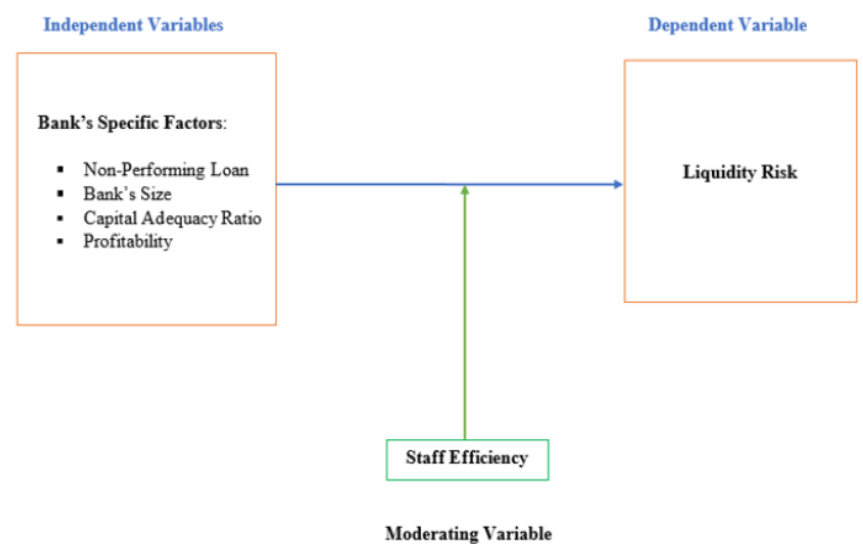

Figure 1. Theoretical framework

The paper argues that adverse changes in the bank's specific variables can be better managed through bank's staff efficiency functions. This can be useful to the banks that have high or low ratios of liquidity risk. However, it is imperative to investigate the moderating role of bank's staff efficiency on the effects of bank's specific variables and liquidity risk. Inevitably, it become vital to empirically assess the moderating impact of staff efficiency on the relationship between bank's specific variables and liquidity risk with the hope that the findings could have relevance on the managing and mitigating liquidity risk of GCC banking sector.

\section{Policy Implications}

The policy implications will be based on the findings of the proposed study on the moderating role of staff efficiency on the relationship between bank's specific variables and liquidity risk in GCC countries. If empirical evidence proofs the moderation impact, then the policy implication could be for the bank's management. The 
bank's management is expected to focus their attention more on staff efficiency. They can incorporate human resource efficiency into key performance indicators of all staff regardless of their specific functions in the bank. This should include all staff involved in risk departments and risk committee, credit managers, relationship staff and credit officers and all liquidity-relationships under their individual portfolios.

\section{Recommendation and Conclusion}

The issue of liquidity risk in GCC banks has attracted very little attention from the scholarly community. To the best knowledge of the researcher this could be the first attempt to study liquidity risk in GCC banks. Therefore, the study is limited to identification of bank's factors determining liquidity risk as the first stage of liquidity risk management. For this reason, it is recommended that a new empirical research to be conducted on liquidity risk in GCC banks to include new critical external and internal variables like oil prices and staff efficiency.

Callen et al. (2015), stated that rise in oil prices in GCC leads to higher oil revenues which translates to a stronger government spending resulting in higher non-oil output growth, greater bank liquidity and credit growth, higher real estate prices, and stronger bank balance sheets. Conversely, in the event of oil price downturn, these developments can reverse, which means tight bank's liquidity which indicates a higher liquidity risk. As an illustration, a continued drop in oil prices can lead to a decrease in the liquidity of banks in GCC (Khandelwal et al., 2016; Alodayni, 2016). This decline in liquidity position induces liquidity risk in these banks. Therefore, it becomes vital for researchers to test the impact of oil prices fluctuations on the financial risks like liquidity and credit risks in GCC banks, whether conventional or Islamic. Also, it is recommended for future research to include staff efficiency variable in their studies of financial risks in other regions like Malaysia and other Islamic countries and non-Islamic countries for comparison purposes.

From Islamic perspective on staff efficiency, Islamic human resources are required to possess key capabilities, behavior (religious, flexible, assertive) and managerial skills (Pariah et al., 2015). Relating this to GCC banks, IMF (2010) reported that the financial crisis of 2008 showed that GCC banks suffer from vulnerabilities related to banks' exposures to asset and weakness in liquidity management. Also, it's been documented that GCC banks suffer from weakness in liquidity risk management, (Kumah et al., 2010) which can be traced back to inefficient staff handing liquidity management.

Thus, there is a pressing need to empirically examine how staff efficiency moderates the relationship between bank's specific factors with liquidity risk in GCC Islamic banks.

The findings could empirically create awareness where the bank's management could devote a considerable attention to staff efficiency due to their importance for building capabilities which should help in managing and mitigating liquidity risk.

To conclude, much uncertainty still exists about the relationship between bank's internal variables and liquidity risk of Islamic banks in GCC countries. This relationship remains unclear how these variables impact the liquidity risk in the banking industry in this vital economic block. Therefore, the current study represents a first attempt to shed light on the liquidity risk determinants in Islamic banks in GCC region. Further study can extend to empirical studies on liquidity risk in this crucial environment in which a significant number of IBs operate.

\section{References}

Abdul G. A., Zainol, Z., \& Ahmad, N. H. (2017). Determinants of liquidity risk in dual and fully Islamic banking systems: Evidence from Malaysia and Sudan. Asian Journal of Multidisciplinary Studies, 5(1), 91.

Abdullah, A., \& Khan, A. Q. (2012). Liquidity risk management: A comparative study between domestic and foreign banks in Pakistan. Journal of Managerial Sciences, 5(1), 62-72.

Acharya, V. V., \& Viswanathan, S. (2011). Leverage, moral hazard, and liquidity. The Journal of Finance, 66(1), 99-138. https://doi.org/10.1111/j.1540-6261.2010.01627.x

Ahmad, N. H., \& Ahmad, S. N. (2004). Key factors influencing credit risk of Islamic bank: A Malaysian case. The Journal of Muamalat and Islamic Finance Research, 1(1), 65-80.

Akkizidis, I., \& Khandelwal, S. K. (2008). Financial Risk Management for Islamic Banking and Finance. New York, NY: Palgrave Macmillan. https://doi.org/10.1057/9780230598751

Al Faris, J., \& Al Zararee, A. N. (2011). The efficiency of liquidity management in Islamic banks (conservative vs. profit). Prace Naukowe Uniwersytetu Ekonomicznego we Wroctawiu, (158), 897-903.

Aldoseri, M. (2012). Risk exposure of Islamic financial institutions: evidence from Gulf Co-operation Council countries. Unpublished PhD Thesis. The University of Newcastle, UK. 
Al-Hassan, A., Oulidi, N., \& Khamis, M. (2010). The GCC banking sector: Topography and analysis. IMF Working Papers, 1/45. Washington D.C.: International Monetary Fund.

Ali, S. S. (2007). Financial distress and bank failure: Lessons from closure of Ihlas Finans in Turkey. Islamic Economic Studies, 14(1-2), 1-52.

Ali, S. S. (2013). State of liquidity management in Islamic financial institutions. Islamic Economic Studies, 21(1), 63-98. https://doi.org/10.12816/0000240

Al-Khouri, R. (2012). Bank Characteristics and Liquidity Transformation: The Case of GCC Banks. International Journal of Economics and Finance, 4(12), 114. https://doi.org/10.5539/ijef.v4n12p114

Al-Khouri, R., \& Dhade, A. (2014). The role of savings in reducing the effect of oil price volatility for sustainable economic growth in oil based economies: The case of GCC countries. International Journal of Economics and Finance. https://doi.org/10.5539/ijef.v6n4p172

Al-Obaidan, A. M. (2008). Efficiency effect of direct lending controls: An empirical study of the Gulf Cooperation Council countries. Investment Management and Financial Innovations, 5(3), 81-89.

Alodayni, S. (2016). Oil Prices, Credit Risks in Banking Systems, and Macro-Financial Linkages across GCC Oil Exporters. International Journal of Financial Studies, 4(4), 23. https://doi.org/10.3390/ijfs4040023

Al-Tamimi, H., Hussein, A., Miniaoui, H., \& Elkelish, W. W. (2015). Financial Risk and Islamic Banks' Performance in the Gulf Cooperation Council Countries. Retrieved October 20, 2017 from https://papers.ssrn.com/sol3/papers.cfm?abstract_id=2664764

Al-Wesabi, H. A., \& Ahmad, N. H. (2013). Credit risk of Islamic banks in GCC countries. International Journal of Banking and Finance, 10(2), 8.

Anam, S., Hasan, S. B., Huda, H. A. E., Uddin, A., \& Hossain, M. M. (2012). Liquidity risk management: A comparative study between conventional and Islamic banks of Bangladesh. Research Journal of Economics, Business and ICT, 5. Retrieved November 6, 2017, from http://www.jitbm.com/40\%20JITBM\%20volumes.html

Ariffin, N. M. (2012). Liquidity risk management and financial performance in Malaysia: Empirical evidence from Islamic banks. Aceh International Journal of Social Science, 1(2).

Babihuga, R. (2007). Macroeconomic and financial soundness indicators: An empirical investigation. IMF Working Paper 07/115. Washington D.C.: International Monetary Fund.

Bariah, N., Hubeis, M., Hafidhuddin, D., \& H. (2015). The determinants of Islamic banking human resource performance: bank syariah mandiri Indonesia. International Journal of Information Technology and Business Management, 40(1), 98-105. Retrieved November 8, 2017 from http://www.jitbm.com/40\%20JITBM\%20volumes.html

Baron, R. M., \& Kenny, D. A. (1986). The moderator-mediator variable distinction in social psychological research: Conceptual, strategic, and statistical considerations. Journal of Personality and Social Psychology, 51(6), 1173. https://doi.org/10.1037/0022-3514.51.6.1173

Basel Committee. (2008). Principles for sound liquidity risk management and supervision. BIS, Basel.

Bessis, J. (2011). Risk management in banking. John Wiley \& Sons.

Boumediene, A. (2015). Financing government budget deficit as a liquidity risk mitigation tool for Islamic banks: A dynamic approach. International Journal of Islamic and Middle Eastern Finance and Management, 8(3), 329-348. http://dx.doi.org/doi:10.1108/IMEFM-04-2014-0038

Callen, Khandelwal, Miyajima, \& Santos. (2015). Oil prices, financial stability, and the use of countercyclical macroprudential policies in the GCC. In IMF conference on "Annual Meeting of Ministers of Finance and Central Bank Governors," Doha, Qatar. Retrieved 17th August 2016 from http://www.imf.org/external/pp/longres.aspx?id=5008

Calomiris, C. W., \& Kahn, C. M. (1991). The role of demandable debt in structuring optimal banking arrangements. The American Economic Review, 497-513.

Chagwiza, W. (2014). Zimbabwean Commercial Banks Liquidity and Its Determinants. International Journal of Empirical Finance, 2(2), 52-64.

Cucinelli, D. (2013). The determinants of bank liquidity risk within the context of euro area. Interdisciplinary Journal of Research in Business, 2(10), 51-64. 
Danuwirana, E. B. (2012). Empat Kompetensi Pengelolaan SDM Berbasis Syariah. Republika.

Diamond, D. W., \& Dybvig, P. H. (1983). Bank runs, deposit insurance, and liquidity. The Journal of Political Economy, 401-419. https://doi.org/10.1086/261155

Diamond, D. W., \& Rajan, R. G. (2005). Liquidity shortages and banking crises. The Journal of Finance, 60(2), 615-647. https://doi.org/10.1111/j.1540-6261.2005.00741.x

Ferrouhi, E. M. (2014). Bank liquidity and financial performance: Evidence from Moroccan banking industry. Business: Theory \& Practice, 15(4). https://doi.org/10.3846/btp.2014.443

Garcia, M. T. M., \& Guerreiro, J. P. S. M. (2016). Internal and external determinants of banks' profitability: The Portuguese case. Journal of Economic Studies, 43(1), 90-107. http://dx.doi.org/10.1108/JES-09-2014-0166

Ghaderi, H., Nazaripoor, M., \& Khaksar, M. (2013). The effect of management skills on managing liquidity (Case study: State banks in the city of Sanandaj. Journal of Basic and Applied Scientific Research, 3(6), 65-78. $\quad$ Retrieved $\quad$ November $\quad 8, \quad 2017$ from https:/www.textroad.com/pdf/JBASR/J.\%20Basic.\%20Appl.\%20Sci.\%20Res.,\%203(6)65-78,\%202013.pdf

Ghenimi, A., \& Omri, M. A. B. (2015). Liquidity risk management:A comparative study between Islamic and conventional banks. Arabian Journal of Business and Management Review, 3(6), 25-30. http://dx.doi.org/10.4172/2223-5833.1000166

Gorton, G., \& Metrick, A. (2012). Securitized banking and the run on repo. Journal of Financial Economics, 104(3), 425-451. https://doi.org/10.1016/j.jfineco.2011.03.016

Grassa, R. (2012). Islamic banks' income structure and risk: Evidence from GCC countries. Accounting Research Journal, 25(3), 227-241. https://doi.org/10.1108/10309611211290185

Hassan, M. K., \& Bashir, A. H. M. (2003, December). Determinants of Islamic banking profitability. In 10th ERF annual conference, Morocco (pp. 16-18).

How, J. C., Karim, M. A., \& Verhoeven, P. (2005). Islamic financing and bank risks: The case of Malaysia. Thunderbird International Business Review, 47(1), 75-94. https://doi.org/10.1002/tie.20041

Ibe, S. O. (2013). The impact of liquidity management on the profitability of banks in Nigeria. Journal of Finance and Bank Management, 1(1), 37-48. Retrieved October 20, 2017 from http://jfbmnet.com/journals/jfbm/Vol_1_No_1_June_2013/4.pdf

Imbierowicz, B., \& Rauch, C. (2014). The relationship between liquidity risk and credit risk in banks. Journal of Banking \& Finance, 40, 242-256. https://doi.org/10.1016/j.jbankfin.2013.11.030

Iqbal, A. (2012). Liquidity Risk Management: A comparative study between Conventional and Islamic banks of Pakistan. Global Journal of Management and Business Research, 12(5). Retrieved October 22, 2017 from https://globaljournals.org/GJMBR_Volume12/6-Liquidity-Risk-Management.pdf

Islamic Financial Services Board (IFSB). (2015). IFSB Report. IFSB. Retrieved October 22, 2017 http://www.ifsb.org/docs/IFSB\%20Islamic\%20Financial\%20Services\%20Industry\%20Stability\%20Report $\% 202015$ final.pdf

Islamic Financial Services Board. (2016). Industry Financial Stability Report, May, 2016. Islamic Financial Services. Retrieved 20th September 2016 from http://www.ifsb.org/sec03.php

Jedidia, K. B., \& Hamza, H. (2015). Determinants of liquidity risk in Islamic banks: A Panel Study. Islamic Management and Business, 7(16), 1-10.

Kosmidou, K., Tanna, S., \& Pasiouras, F. (2005, June). Determinants of profitability of domestic UK commercial banks: panel evidence from the period 1995-2002. In Money Macro and Finance (MMF) Research Group Conference (Vol. 45, pp. 1-27).

Kumah, F. Y., Hasan, M., Khamis, M. Y., Prasad, A., Semlali, A. S., \& Sensenbrenner, G. (2010). Impact of the global financial crisis on the Gulf Cooperation Council countries and challenges ahead. IMF Working Paper 43/2010. Washington D.C.: International Monetary Fund. Retrieved October 25, 2017 from https://www.imf.org/external/pubs/ft/dp/2010/dp1002.pdf

Lanine, G., \& Vander Vennet, R. (2006). Failure prediction in the Russian bank sector with logit and trait recognition models. Expert Systems with Applications, 30(3), 463-478. https://doi.org/10.1016/j.eswa.2005.10.014

Loghod, H. A. (2010). Do Islamic banks perform better than conventional banks? Evidence from gulf 
cooperation council countries (No. 1011). Retrieved October 25, 2017, from http://www.arab-api.org/images/publication/pdfs/297/297_wps1011.pdf

Mahmoud, M. (2016). Gulf Islamic Finance in a Time of Austerity. Retrieved May 5, 2016 from http://www.agsiw.org/wp-content/uploads/2016/06/Mai_Mahmoud_ONLINE-6.pdf

Majid, A., \& Rais, A. (2003, March). Development of liquidity management instruments: challenges and opportunities. In International Conference on Islamic Banking: Risk Management, Regulation and Supervision, held in Jakarta Indonesia September. Retrieved October 25, 2017 from http://www.sbp.org.pk/departments/ibd/Lecture_6_LIQUIDITY_MANAGEMENT.pdf

Mohamad, A. A. S., Mohamad, M. T., \& Samsudin, M. L. (2013). How Islamic banks of Malaysia managing liquidity? An emphasis on confronting economic cycles. International Journal of Business and Social Science, 4(7). Retrieved October 5, 2017 from http://ijbssnet.com/journals/Vol_4_No_7_July_2013/28.pdf

Mohanty, S. K., Lin, H. J., Aljuhani, E. A., \& Bardesi, H. J. (2016). Banking Efficiency in Gulf Cooperation Council (GCC) Countries: A Comparative Study. Review of Financial Economics, 31, 99-107. https://doi.org/10.1016/j.rfe.2016.06.004

Mohd-Sultan, S. A. (2008). Islamic banking: Trend, development and challenges. Essential Readings in Islamic Finance, CERT Publications Sdn. Bhd.

Nemati. M., Ghanbari, M., \& Mohammadipour, R. (2015). An examination of impact of liquidity risk management on continuing financial performance and activities of listed bank of Tehran stock exchange. International Journal of Review in Life Sciences.

Nimsith, S., \& Shibly, F. (2015). Liquidity Risk Management in Islamic and Conventional Banks in Sri Lanka: Comparative Study. International Journal of Management, Information Technology and Engineering, 3(9), 7-22. $\quad$ Retrieved $\quad$ October $\quad 10, \quad 2017$ from https://www.researchgate.net/publication/281422923_LIQUIDITY_RISK_MANAGEMENT_IN_ISLAMI C_AND_CONVENTIONAL_BANKS_IN_SRI_LANKA_A_COMPARATIVE_STUDY

Nor, A. M., \& Ahmad, N. H. (2015). Impaired financing determinants of Islamic banks in Malaysia. Information Management and Business Review, 7(3), 17. Retrieved October 10, 2017 from https://www.researchgate.net/search.Search.html?type=publication\&query=Impaired\%20Financing\%20Det erminants\%20of\%20Islamic\%20Banks\%20in\%20Malaysia

Obeidat, Z. M. (2016). Human capital investment and training in Islamic banking industry in Jordan Islamic bank for finance and investment. European Scientific Journal, ESJ, 12(10). Retrieved November 9, 2017 from https://www.eujournal.org/index.php/esj/article/viewFile/7313/7060

Ramzan, M., \& Zafar, M. I. (2014). Liquidity risk management in Islamic Banks: A study of Islamic banks of Pakistan. Interdisciplinary Journal of Contemporary Research In Business, 5(12), 199-215. Retrieved October 5, 2017 from https://journal-archieves36.webs.com/199-215apr14.pdf

Ravichandran, K., \& Alkhathlan, K. A. (2010). Impact of oil prices on GCC stock market. Research in Applied Economics, 2(1). https://doi.org/10.5296/rae.v2i1.435

Rivard, R. J., \& Thomas, C. R. (1997). The effect of interstate banking on large bank holding company profitability and risk. Journal of Economics and Business, 49(1), 61-76. https://doi.org/10.1016/S0148-6195(96)00041-0

Salameh, R. M. (2014). Reading in the History of Islamic Banks Bankruptcy: The Jordanian Case. International Journal of Finance and Accounting, 3(4), 227-234. Retrieved from http://economics.usf.edu/PDF/Rivard\%20and\%20Thomas\%201997\%20interstate\%20banking.pdf

Shaikh, S. A. (2015). Panel Data Estimation of Liquidity Risk Determinants in Islamic Banks: A Case Study of Pakistan. Journal of Islamic Banking \& Finance, 32(4). Retrieved October 7, 2017 from https://www.researchgate.net/publication/289531777_Panel_Data_Estimation_of_Liquidity_Risk_Determin ants_in_Islamic_Banks_A_Case_Study_of_Pakistan

Sharma, S., Durand, R. M., \& Gur-Arie, O. (1981). Identification and analysis of moderator variables. Journal of Marketing Research, 291-300. https://doi.org/10.2307/3150970

Sohaimi, A. N. A. (2013). Liquidity Risk and Performance of Banking System in Malaysia. https://doi.org/10.2139/ssrn.2271427

Sufian, F., \& Habibullah, M. S. (2009). Determinants of bank profitability in a developing economy: Empirical 
evidence from Bangladesh. Journal of Business Economics and Management, 10(3), 207-217. http://dx.doi.org/10.3846/1611-1699.2009.10.207-217

Van Greuning, H., \& Brajovic-Bratanovic, S. (2009). Analysing banking risk: A framework for assessing corporate governance and risk management. World Bank Publications. Retrieved October 10, 2017 from https://openknowledge.worldbank.org/handle/10986/2618

Vodová, P. (2013). Determinants of commercial bank liquidity in Hungary. E-Finanse, 9(3), 64. Retrieved November $\quad 8, \quad 2017 \quad$ from http://e-finanse.com/archives/?page=wpabstracts\&tab=attachments\&task=download $\&$ type $=$ attachment\&id $=$ 234

Wasiuzzaman, S., \& Nair Gunasegavan, U. (2013). Comparative study of the performance of Islamic and conventional banks: The case of Malaysia. Humanomics, 29(1), 43-60. http://dx.doi.org/10.1108/08288661311299312

Wasiuzzaman, S., \& Tarmizi, H. A. B. A. (2010). Profitability of Islamic banks in Malaysia: An empirical analysis. Journal of Islamic Economics, Banking and Finance, 6(4), 53-68.

Zaghdoudi, K., \& Hakimi, A. (2017). The determinants of liquidity risk: Evidence from Tunisian banks. Journal of Applied Finance and Banking, 7(2), 71. Retrieved October 10, 2017 from https://econpapers.repec.org/RePEc:spt:apfiba:v:7:y:2017:i:2:f:7_2_5

\section{Appendix A}

The related literature on the determinants of liquidity risk

\begin{tabular}{|c|c|c|c|c|}
\hline No. & Title \&Author (s) & Method/Context/ Sampling & Dependent variable & Independent Variables \\
\hline 1 & $\begin{array}{l}\text { Al-Khouri } \\
(2012) \\
\text { GCC }\end{array}$ & $\begin{array}{l}\text { Panel data } \\
43 \text { banks } \\
1998-2008\end{array}$ & $\begin{array}{l}\text { Liquidity transformation gap: } \\
\text { (liquid liabilities - liquid } \\
\text { assets)/Total assets }\end{array}$ & $\begin{array}{l}\text { capital ratio, government ownership } \\
\text { Control variables: bank specific characteristics } \\
\text { and macroeconomic indicators }\end{array}$ \\
\hline 2 & $\begin{array}{l}\text { Jedidia \&Hamza } \\
(2014) \\
\text { MENA and } \\
\text { South-eastern Asia }\end{array}$ & $\begin{array}{l}\text { Dynamic panel data } \\
\text { estimations, GMM } \\
60 \text { banks } \\
2004-2012\end{array}$ & $\begin{array}{l}\text { Liquidity1: Loan to Asset } \\
\text { Ratio } \\
\text { Liquidity } 2 \text { = Cash/total assets }\end{array}$ & $\begin{array}{l}\text { (Bank size, Capital adequacy ratio, Return on } \\
\text { Asset, Investment assets), (GDP real growth } \\
\text { rate). }\end{array}$ \\
\hline 3 & $\begin{array}{l}\text { Ghenimi } \\
(2015) \\
\text { GCC }\end{array}$ & $\begin{array}{l}\text { Panel data, ordinary least } \\
\text { squares (OLS) } \\
11 \text { IBs and } 33 \text { CBs } \\
2006-2013\end{array}$ & $\begin{array}{l}\text { ROA } \\
\text { net interest margin }\end{array}$ & $\begin{array}{l}\text { liquidity risk (liquid asset to total asset), CAR, } \\
\text { non -NPLs (impaired loans to gross loans, size } \\
\text { of the bank, inflation rate and GDP }\end{array}$ \\
\hline 4 & $\begin{array}{l}\text { Iqbal, Ibrahim \& } \\
\text { Murtaza, } \\
\text { (2015) } \\
\text { Pakistan }\end{array}$ & $\begin{array}{l}\text { Simple linear regression, } \\
\text { SPSS } \\
20 \text { banks } \\
1991-2011\end{array}$ & $\begin{array}{l}\text { Liquidity Risk: } \\
\text { cash and total assets }\end{array}$ & $\begin{array}{l}\text { ROA, ROE, CAR, NIM, liquidity gaps, and } \\
\text { RLA (the ratio of risky liquidity assets to total } \\
\text { assets) }\end{array}$ \\
\hline 5 & $\begin{array}{l}\text { Yaacob, Rahman \& } \\
\text { Karim } \\
(2016)\end{array}$ & $\begin{array}{l}\text { Fixed effect \& random effect } \\
\text { models } \\
17 \text { Islamic Banks }\end{array}$ & $\begin{array}{l}\text { Liquidity coverage ratio (LCR) } \\
\text { Net Stable Funding Ratio } \\
\text { (NSFR) }\end{array}$ & $\begin{array}{l}\text {-Size, capital adequacy ratio, profitability, } \\
\text { asset quality and bank specialization } \\
\text { - GDP and inflation }\end{array}$ \\
\hline 6 & $\begin{array}{l}\text { Malaysia } \\
\text { Alodayni } \\
(2016) \\
\text { GCC }\end{array}$ & $\begin{array}{l}2000 \text { - } 2013 \\
\text { GMM, Panel VAR model, } \\
38 \text { banks (Islamic and } \\
\text { Conventional) }\end{array}$ & Credit Risk (NPLs) & $\begin{array}{l}\text { NPLs, oil prices, non-oil GDP, lending interest } \\
\text { rate, credit growth, stock prices, and housing } \\
\text { prices }\end{array}$ \\
\hline 7 & $\begin{array}{l}\text { Zaghdoudi \& Hakimi } \\
\text { (2017) } \\
\text { Tunisia }\end{array}$ & $\begin{array}{l}2000 \text { - } 2014 \\
\text { Panel data analysis } \\
10 \text { conventional banks } \\
1980 \text { - } 2015\end{array}$ & $\begin{array}{l}\text { Liquidity Risk }(\mathrm{LR})=\text { loans to } \\
\text { total deposits }\end{array}$ & $\begin{array}{l}\text { activity of loan granting, Capital adequacy } \\
\text { ratio size, Credit risk, financial crisis } \\
\text { concentration of the banking market }\end{array}$ \\
\hline
\end{tabular}

Source: Authors' work (2017).

\section{Copyrights}

Copyright for this article is retained by the author(s), with first publication rights granted to the journal.

This is an open-access article distributed under the terms and conditions of the Creative Commons Attribution license (http://creativecommons.org/licenses/by/4.0/). 